\section{Effect of $3 \beta$, hydroxy-lup- 20(29)-en-28-oic acid on 7,12-Dimethylbenz(a) anthracene impaired cellular homeostasis in extrahepatic organs of Sprague Dawley rats}

Pardeep Kaur, ${ }^{1}$ Rajbir Kaur, ${ }^{2}$ Rohit Arora, ${ }^{1}$ Saroj Arora ${ }^{1}$

${ }^{1}$ Department of Botanical and Environmental Sciences, Guru Nanak Dev University, Amritsar; ${ }^{2}$ Department of Botany, Sri Guru Teg Bahadur Khalsa College, Sri Anandpur Sahib, Ropar, India

\begin{abstract}
$3 \beta$, hydroxy-lup-20(29)-en-28-oic acid (Betulinic acid), a pentacyclic lupane-type triterpene has diverse pharmacological functions both in vitro and in vivo. The present study focuses its protective effect on polycyclic aromatic hydrocarbon (7,12Dimethylbenz(a)anthracene or DMBA) induced alterations in membrane bound ATPases, detoxification enzymes and antioxidant enzymes in stomach and lungs of female Sprague Dawley rats. Healthy female Sprague Dawley rats were randomly assorted into six groups and the treatments were given orally for 7 weeks on alternate days. It was observed that betulinic acid facilitated the downregulation of elevated membrane bound ATPases $\left(\mathrm{Na}^{+} / \mathrm{K}^{+}\right.$ATPase, $\mathrm{Ca}^{2+}$-ATPase and $\mathrm{Mg}^{2+}$-ATPase) in DMBA administered rats. Likewise, the detoxification enzymes as well as antioxidant enzymes were modulated to normalcy in rats. Overall, betulinic acid was seen to be effective modulator of DMBA induced alterations in biochemical parameters.
\end{abstract}

\section{Introduction}

Xenobiotics are responsible for a varied degree of stress in humans and animals. The exposure to xenobiotics may occur deliberately (food additives), accidentally (food contaminants and pesticides) or coincidentally (industrial chemicals and environmental pollutants/mutagens) which lead to oxidative stress triggering spread of various diseases and cancer. ${ }^{1,2}$ Thus, the myriad of enzyme systems have evolved to assist the disposition of xenobiotics and to retain cellular homeostasis. Xenobiotic metabolizing enzymes in the extrahepatic tissues of ani- mals serve the additional purpose of detoxification defence against toxins that mainly act on these organs. In addition, liver diseases (cirrhosis, infection, necrosis etc.) or the damage of organ compromise the role of liver by shifting the dependence for drug disposition to extrahepatic tissues. ${ }^{3}$ The gastrointestinal tract (GIT) is the second major site in the body for detoxification. It is the main portal of entry for a wide array of compounds including xenobiotics as most of the contaminants and pollutants are consumed orally. During the entire life span, gastrointestinal tract processes more than 25 tons of food which correspond to the largest load of xenobiotics confronting the body parts. ${ }^{4}$ Nearly $75 \%$ of the blood reaching the liver arrives directly from gastrointestinal organs and then spleen via hepatic portal vein. ${ }^{5}$ The lungs can absorb, modify and excrete out the foreign substances and drugs. ${ }^{6}$ They are situated at the air/blood interface and play a noteworthy role in the elimination of variety of compounds. ${ }^{7}$ The complex architecture of lungs reflects over 40 different cell types with remarkable diversity in cell functionality and is capable of extracting drugs from the blood circulation because all the cardiac output goes through it. ${ }^{8,9}$

7,12-Dimethylbenz(a)anthracene (DMBA) is a class of polycyclic aromatic hydrocarbon (PAH). It is absorbed mainly through the skin, respiratory, intestinal tracts; by ingestion and inhalation. ${ }^{10}$ The induction of gastric cancer in rats by injecting DMBA in the glandular stomach has been reported in literature. ${ }^{11}$ Previous reports have also shown the DMBA induced tumor formation in forestomach of mouse. ${ }^{12}$ It was also found that lungs showed occasional tumors after intraperitoneal injection of DMBA. ${ }^{13}$ In other reports, DMBA has been found to induce neoplasms in the mammary gland, liver, heart and lungs after being metabolically activated. ${ }^{14}$

$3 \beta$, hydroxy-lup-20(29)-en-28-oic acid (Betulinic acid), a pentacyclic lupane-type triterpene is a phytochemical agent and has various botanical sources like Betula alba, Tryphyllum peltatum, Ancistrocladus heyneaus, Diospyros leucomelas, Tetracera boliviana, Zizyphus joazeiro, Syzygium formosanum etc. Various fruits and vegetables are also a good source of this compound. ${ }^{15-}$ ${ }^{17}$ Betulinic acid is known for various biological activities including anti-inflammatory, anti-viral, anti-neoplastic, anti-tumor, and anti-HIV. ${ }^{18-22}$ Its anti-tumor activity has also been reported in human neoplastic cell lines including lung, ovarian, cervical, colorectal, breast and prostate. ${ }^{23}$ Induction of apoptosis via direct mitochondrial alterations, formation of reactive oxygen
Correspondence: Saroj Arora, Professor, Department of Botanical and Environmental Sciences, Guru Nanak Dev University, Amritsar-143005, Punjab, India.

Tel.: +91.9417285485

E-mail: sarojarora.gndu@gmail.com

Key words: $3 \beta$, hydroxy-lup-20(29)-en-28-oic acid; 7,12-Dimethylbenz(a)anthracene; extrahepatic organs; xenobiotics; oxidative stress; polycyclic aromatic hydrocarbon.

Acknowledgements: the authors gratefully acknowledge UGC, New Delhi, for providing financial support under MANF, UPE and CPEPA to manage resources for executing the research project and to achieve the objectives. Dr. Amritpal Singh, Assistant Professor, Department of Pharmaceutical Sciences, Guru Nanak Dev University, Amritsar (India) is also duly acknowledged for his help in conducting the studies.

Contributions: PK carried out the biochemical alteration study in stomach and lung of female Sprague Dawley rats, performed the statistical analysis and drafted the manuscript. RK conceived of the study, participated in its design and helped to draft the manuscript. RA analyzed the data and helped to draft the manuscript. SA contributed reagents/materials/ analysis tools, design and coordination and helped to draft the manuscript. All authors read and approved the final manuscript.

Conflict of interest: the authors declare no conflict of interest.

Received for publication: 27 December 2016 Revision received: 15 February 2017.

Accepted for publication: 15 February 2017.

This work is licensed under a Creative Commons Attribution NonCommercial 4.0 License (CC BY-NC 4.0).

(C) Copyright P. Kaur et al., 2017

Licensee PAGEPress, Italy

Journal of Xenobiotics 2017; 7:6475

doi:10.4081/xeno.2017.6475

species, modulation of BCL-2 and BAX levels and topoisomerases $\mathrm{I} \alpha$ and II $\alpha$ have been suggested as its possible mechanism of action. . $^{24,25}$

A number of in vivo studies have shown betulinic acid to be effective against carcinogen induced hepatotoxicity with fewer studies probing its effect in DMBA evoked extrahepatic damage. ${ }^{26}$ The available literature on detoxification highlights the liver as the chief site of detoxification activity for both endogenous and exogenous toxins. The focus on biotransformation of chemical assaults (xenobiotics) in extrahepatic organs is limited. Keeping in mind the aforementioned facts, the present study 
extends this observation by examining the intervention of betulinic acid with DMBA induced alterations in membrane bound ATPases, detoxification enzymes and antioxidant enzymes in stomach and lungs of female Sprague Dawley rats.

\section{Ethical approval for animal research}

The animals were sheltered in the central animal house of Guru Nanak Dev University, Amritsar as per strict compliance with the guidelines of Committee for the Purpose of Control and Supervision of Experiments on Animals (CPCSEA), Ministry of Environment and Forests, Government of India. The experimental protocol was duly reviewed and approved by the Institutional Animal Ethics Committee, Guru Nanak Dev University, Amritsar, India (671/BT dated May 20, 2011).

\section{Materials and Methods}

Studies were carried out using healthy female Sprague Dawley rats (8-12 weeks old), weighing 140-200 g, procured from National Institute of Pharmaceutical Education and Research (NIPER), Mohali, Punjab (India). The animals were randomly assorted into 6 groups ( $\mathrm{n}=6$ for each group) and then treated with DMBA, test compound betulinic acid and standard compound indole-3-carbinol (I3C). This polycyclic aromatic hydrocarbon (DMBA) is an important chemical in inducing mutagenesis and carcinogenesis in animal models. ${ }^{27}$ The different concentrations of betulinic acid, DMBA and I3C were made using peanut oil (used as control vehicle) administered as per body weight (bw) and the compounds were given to animals via oral route. The different groups are described in Table 1. The treatments were made for seven weeks on alternate days and the experiment was terminated at the end of $14^{\text {th }}$ week. Animals were sacrificed by cervical dislocation following overnight fasting.

\section{Preparation of homogenate}

The entire stomach and lung of animals were isolated, perfused immediately with cold $0.9 \% \mathrm{NaCl}$, cleaned of adhering fat and connective tissues and thereafter rinsed in chilled $0.15 \mathrm{M}$ Tris- $\mathrm{KCl}$ buffer $(0.15 \mathrm{M}$ $\mathrm{KCl}+10 \mathrm{mM}$ Tris-HCl, $\mathrm{pH}$ 7.4). The organs were then blotted dry, w e i g h e d quickly and homogenized in ice cold 0.15 $\mathrm{M}$ Tris- $\mathrm{KCl}$ buffer to yield $10 \%(\mathrm{w} / \mathrm{v})$ homogenate. Homogenate $(0.5 \mathrm{ml})$ was then precipitated with $5 \%$ trichloroacetic acid, centrifuged at $2000 \mathrm{rpm}$ and the supernatant was used for the estimation of reduced glutathione content. The homogenate, after discarding lipid layer was used for the estimation of various biochemical parameters.

\section{Biochemical analysis}

\section{Estimation of membrane bound ATPases}

$\mathrm{Na}^{+} / \mathrm{K}^{+}$-ATPase was determined according to the method of Bonting. ${ }^{28} \mathrm{Ca}^{2+}-$
ATPase was assayed as described by Hjerten and Pan. ${ }^{29} \mathrm{Mg}^{2+}$-ATPase was determined by the method of Ohnishi et al. ${ }^{30}$ The supernatant was used for the estimation of phosphorous content as per the method described by Fiske and Subbarow. ${ }^{31}$

\section{Estimation of detoxification enzymes}

Glutathione-S-transferase (EC 2.5.1.18) activity was determined spectrophotometrically at $37^{\circ} \mathrm{C}$ as described by Habig et al..$^{32}$ $\mathrm{NAD}(\mathrm{P}) \mathrm{H}$ :quinone oxidoreducatse (EC 1.6.99.2) also known as DT-diaphorase was measured as described by Ernster. ${ }^{33}$

\section{Estimation of antioxidant enzymes}

The activity of superoxide dismutase (EC 1.15.1.1) was assayed following the method given by Kono with slight modifications. ${ }^{34}$ Catalase (EC 1.11.1.6) activity was estimated following the method given by Aebi. ${ }^{35}$ Activity of Ascorbate peroxidase (EC 1.11.1.11) was determined using method given by Asada. ${ }^{36}$ Guaiacol peroxidase (EC 1.11.1.7) was assayed by the procedure described by Putter with slight modifications. ${ }^{37}$ Glutathione reductase (EC 1.8.1.7) was determined by the procedure described by Carlberg and Mannervik. ${ }^{38}$ Lactate dehydrogenase (EC 1.1.1.27, L-lactate: $\mathrm{NAD}^{+}$oxidoreductase) activity was determined following the method of Kuznetsov and Gnaiger with slight modifications. $^{39}$

\section{Estimation of oxidative stress parameters}

Lipid Peroxidation (LPO) was estimated as evidenced by the formation of

Table 1. The treatment protocol of Betulinic acid, DMBA and I3C among the Sprague Dawley female rats assorted in 6 groups ( $=6$ for each group).

\section{Treatment Protocol}

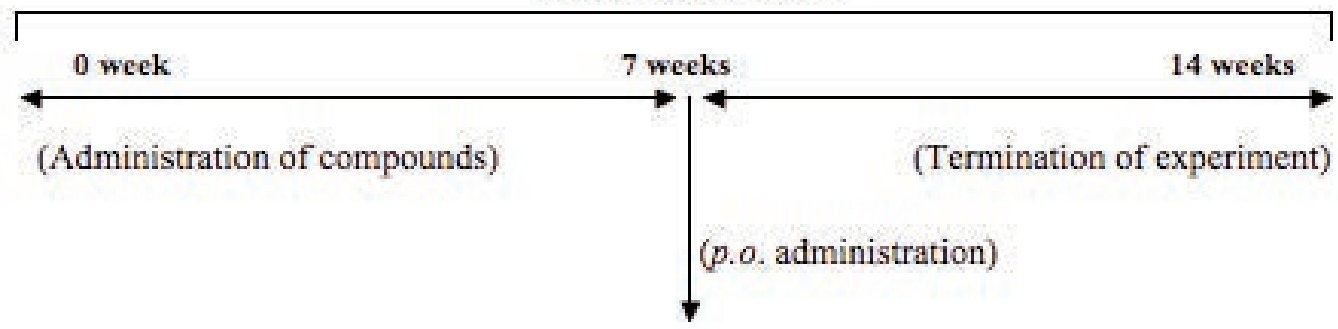

\begin{tabular}{lccc} 
Groups & Compound & Concentration & Treatiment type \\
I & Standard pellet diet and tap water ad libitum & - & Untreated Control \\
II & DMBA & $10 \mathrm{mg} / \mathrm{kg} \mathrm{bw}$ & Mutagen \\
\hline III & DMBA+ Betulinic acid & $10 \mathrm{mg} / \mathrm{kg} \mathrm{bw}+2 \mathrm{mg} / \mathrm{kg} \mathrm{bw}$ & Treatment groups to check the \\
IV & DMBA+ Betulinic acid & $10 \mathrm{mg} / \mathrm{kg} \mathrm{bw}+5 \mathrm{mg} / \mathrm{kg} \mathrm{bw}$ & inhibitory effect of test compound \\
V & DMBA+ Betulinic acid & $10 \mathrm{mg} / \mathrm{kg} \mathrm{bw}+10 \mathrm{mg} / \mathrm{kg}$ bw & \\
VI & DMBA+ Indole-3-carbinol & $10 \mathrm{mg} / \mathrm{kg} \mathrm{bw}+10 \mathrm{mg} / \mathrm{kg}$ bw &
\end{tabular}


Thiobarbituric Acid Reactive Species (TBARS) and lipid hydroperoxides following the method of Devasagayam et al. and Jiang et al. respectively with slight modifications. ${ }^{40,41}$ The amount of reduced glutathione (GSH) was determined using method described by Anderson. ${ }^{42}$

\section{Determination of protein content}

The protein content of various samples was determined using the method given by Smith et al. using BSA as a standard. ${ }^{43}$

\section{Statistical analysis}

The experimental data were expressed as mean $\pm \mathrm{SE}$. One-way analysis of variance (ANOVA) and HSD value were carried out to determine significant differences between the means at $\mathrm{P} \leq 0.05$.

\section{Results}

\section{Betulinic acid modulates DMBA induced impairment of membrane bound ATPases}

ATPases are lipid dependent membrane bound enzymes responsible for cellular viability by controlling several crucial cellular functions. Transmembrane ATPases import many of the metabolites necessary for cell metabolism and export toxins, wastes, and solutes that can hinder cellular processes. Changes in the activities of these enzymes either deteriorate or accelerate the different pathological conditions. ${ }^{44}$ In stomach, DMBA treatment (Group II) resulted in the higher amount of phosphorous liberation as compared to the untreated control (Table 2). The oral supplementation of betulinic acid and $\mathrm{I} 3 \mathrm{C}$ (known anticarcinogen) in combination with DMBA at all the tested doses showed the decrease in $\mathrm{Na}^{+} / \mathrm{K}^{+}$-ATPase activity in both stomach and lung homogenate as compared to Group II animals. Similar results were obtained in the activity of $\mathrm{Ca}^{2+}$-ATPase in stomach as well as lungs (Group III, IV, V and VI). In the case of $\mathrm{Mg}^{2+}$-ATPase, group III, V and VI witnessed significant reduction of its activity in stomach compared to DMBA group. Similar results were observed in lung homogenate of betulinic acid treatment groups III and IV.

\section{Betulinic acid modulates DMBA induced impairment of detoxifica- tion enzymes}

Exposure of rats to DMBA resulted in the decreased activity of GST as compared to the control group in stomach. While, GST increased activity was noted in case of the lung. The treatment of $\mathrm{I} 3 \mathrm{C}$ and three tested doses of betulinic acid lowered the GST activity as compared to DMBA group in both stomach and lung. Extrahepatic DTdiaphorase enzyme activity in case of DMBA treated rats showed increased activity in comparison to untreated control. The specific activity was found to be lowered on betulinic acid administration in both organs except at betulinic acid $5 \mathrm{mg} / \mathrm{kg}$ bw in the stomach (Table 3).

\section{Betulinic acid modulates DMBA induced impairment of antioxidant enzymes}

Table 4 depicts the activities of various antioxidant enzymes among different treatment groups. DMBA treated group elicited increased SOD activity as compared to control in both the extrahepatic organs (stom-

Table 2. Modulation of DMBA induced impairment of membrane bound ATPases by betulinic acid among different treatment groups of female Sprague Dawley rats.

\begin{tabular}{|c|c|c|c|c|c|c|c|c|}
\hline Parameter & Group I & Group II & Group III & Group IV & Group V & Group VI & F-ratio & HSD value \\
\hline \multicolumn{9}{|c|}{$\begin{array}{l}\mathrm{Na}^{+} / \mathrm{K}^{+}-\mathrm{ATPase} \\
\text { ( } \mu \text { moles of phosphate } \\
\text { liberated/min/mg protein) }\end{array}$} \\
\hline Stomach & $67.120^{\mathrm{a}} \pm 0.329$ & $185.821^{\mathrm{b}} \pm 0.616$ & $26.890^{c} \pm 0.0587$ & $102.770^{\mathrm{d}} \pm 1.017$ & $32.830^{\mathrm{e}} \pm 0.386$ & $157.250^{\mathrm{f}} \pm 0.673$ & $5.064^{*}$ & 0.1528 \\
\hline Lung & $29.698^{\mathrm{a}} \pm 0.587$ & $60.836^{\mathrm{b}} \pm 0.210$ & $31.815^{\mathrm{c}} \pm 0.645$ & $31.388^{\mathrm{d}} \pm 0.732$ & $40.535^{\mathrm{e}} \pm 0.711$ & $39.493^{\mathrm{f}} \pm 0.268$ & $27.270^{*}$ & 0.0546 \\
\hline \multicolumn{9}{|c|}{$\begin{array}{l}\mathrm{Ca}^{2+} \text {-ATPase } \\
\text { ( } \mu \text { moles of phosphate } \\
\text { liberated/min/mg protein) }\end{array}$} \\
\hline $\begin{array}{l}\text { Stomach } \\
\text { Lung }\end{array}$ & $\begin{array}{c}111.285 \pm 0.501 \\
50.231 \pm 0.036\end{array}$ & $\begin{array}{c}254.410 \pm 0.386 \\
57.348 \pm 0.674\end{array}$ & $\begin{array}{c}61.863 \pm 0.243 \\
104.054 \pm 0.674\end{array}$ & $\begin{array}{l}105.80 \pm 0.558 \\
54.424 \pm 0.471\end{array}$ & $\begin{array}{l}31.913 \pm 0.558 \\
91.757 \pm 0.384\end{array}$ & $\begin{array}{c}136.503 \pm 0.616 \\
62.890 \pm 0.645\end{array}$ & $\begin{array}{l}1.731 \\
1.043\end{array}$ & - \\
\hline \multicolumn{9}{|c|}{$\begin{array}{l}\mathrm{Mg}^{2+} \text {-ATPase } \\
\text { ( } \mu \text { moles of phosphate } \\
\text { liberated/min/mg protein) }\end{array}$} \\
\hline $\begin{array}{l}\text { Stomach } \\
\text { Lung }\end{array}$ & $\begin{array}{l}71.060^{\mathrm{a}} \pm 1.959 \\
44.360^{\circ} \pm 0.442\end{array}$ & $\begin{array}{l}137.650^{\mathrm{b}} \pm 1.80 \\
60.950^{\mathrm{b}} \pm 0.645\end{array}$ & $\begin{array}{c}97.80^{c} \pm 2.458 \\
55.460^{c} \pm 0.181\end{array}$ & $\begin{array}{c}141.190^{\mathrm{d}} \pm 0.2358 \\
56.060^{\mathrm{d}} \pm 0.529\end{array}$ & $\begin{array}{c}40.940^{\mathrm{e}} \pm 2.344 \\
147.95^{0 \mathrm{e}} \pm 0.7011\end{array}$ & $\begin{array}{c}135.490^{\mathrm{f}} \pm 1.732 \\
52.750^{\mathrm{f}} \pm 0.501\end{array}$ & $\begin{array}{c}3.458^{*} \\
12.063^{*}\end{array}$ & $\begin{array}{l}0.2830 \\
0.1482\end{array}$ \\
\hline
\end{tabular}

*Represents significance at $\mathrm{P} \leq 0.05$. Superscripts a-f represents comparison of group I, II, III, IV, V and VI means using HSD value.

Table 3. Modulation of DMBA induced impairment of detoxification enzymes by betulinic acid among different treatment groups of female Sprague Dawley rats.

\begin{tabular}{|c|c|c|c|c|c|c|c|c|}
\hline Parameter & Group I & Group II & Group III & Group IV & Group V & Group VI & F-ratio & HSD value \\
\hline \multicolumn{9}{|c|}{$\begin{array}{l}\text { Glutathione-S-transferase } \\
\text { (milli IU/mg protein) }\end{array}$} \\
\hline Stomach & $8.010^{\mathrm{a}} \pm 0.003$ & $5.870^{\mathrm{b}} \pm 0.004$ & $2.320^{c} \pm 0.002$ & $2.050^{\mathrm{d}} \pm 0.001$ & $1.220^{\mathrm{e}} \pm 0.001$ & $5.140^{f} \pm 0.0028$ & $89.988^{*}$ & 0.00407 \\
\hline Lung & $3.911^{\mathrm{a}} \pm 0.006$ & $9.665^{\mathrm{b}} \pm 0.0018$ & $2.346^{c} \pm 0.0063$ & $2.849^{\mathrm{d}} \pm 0.007$ & $7.9911^{\mathrm{e}} \pm 0.005$ & $2.123^{\mathrm{f}} \pm 0.0018$ & $14.349^{*}$ & 0.00839 \\
\hline \multicolumn{9}{|c|}{$\begin{array}{l}\text { DT- diaphorase } \\
\text { ( } \mu \text { mol IU/mg protein) }\end{array}$} \\
\hline Stomach & $106.70^{\mathrm{a}} \pm 0.085$ & $407.10^{\mathrm{b}} \pm 0.085$ & $361.40^{c} \pm 0.086$ & $541.50^{\mathrm{d}} \pm 0.286$ & $330.10^{\mathrm{e}} \pm 0.171$ & $679.20^{\mathrm{f}} \pm 0.085$ & $10.537^{*}$ & 0.006924 \\
\hline Lung & $319.160 \pm 1.714$ & $431.040 \pm 0.100$ & $408.730 \pm 0.571$ & $268.340 \pm 0.571$ & $254.40 \pm 0.541$ & $278.933 \pm 1.142$ & 2.944 & - \\
\hline
\end{tabular}

*Represents significance at $\mathrm{P} \leq 0.05$. Superscripts a-f represents comparison of group I, II, III, IV, V and VI means using HSD value. 
ach and lung). On the other hand, betulinic acid and I3C treated groups in combination with DMBA were found to have lower SOD activity than DMBA administered rats. The enzymatic activity of CAT in the case of stomach homogenate of DMBA treated group was found to be lowered in contrast to control group. However, co-treatment of betulinic acid with DMBA resulted in the reduced activity of CAT. No significant change was observed in the status of CAT activity in lung among various groups employed in the present study. The specific activity of APOX enzyme was significantly enhanced by DMBA in comparison to normal rats in both the organs. The activity was observed to be lower in all the other treatment groups (III, IV and V of stomach and III of lung). An increase in the level of enzymatic activity of GPOX was observed in stomach and lung on administration of DMBA as compared to untreated group. All the other tested doses of betulinic acid and I3C in combination with DMBA employed in the present study showed reduced enzymatic level. Both the extrahepatic organs showed reduced GR activity in DMBA treated group in comparison to control group. Betulinic acid treatment groups resulted in a significant increase in the specific activity as compared to DMBA group.
LDH activity was found to be lowered in DMBA group as compared to the control group. The treatment with betulinic acid resulted in an increase in the specific activity in both organs.

\section{Betulinic acid modulates DMBA induced oxidative stress}

As depicted in Table 5, a significant increase in lipid peroxidation was observed in DMBA group when compared with the normal control in both the extrahepatic organs. DMBA induced increment in lipid peroxidation was observed to be lowered on co-treatment with betulinic acid and I3C. The amount of lipid hydroperoxides was found to be very low in DMBA treated rats among different treatment groups in stomach and lung. Betulinic acid co-administration elevated the lipid hydroperoxide content at all the given tested doses. A marked decrease in the extrahepatic GSH level was observed in DMBA recipient animals than the normal control. The treatment with betulinic acid and $\mathrm{I} 3 \mathrm{C}$ afforded protection by elevating the GSH level in comparison to DMBA treatment group at all the tested doses.

\section{Protein content analysis}

Group II animals that received DMBA showed decreased protein content as compared to untreated control. Administration of betulinic acid and I3C in combination with DMBA resulted in higher protein content in the stomach and lungs of rats (gp IV, $\mathrm{V}$ and $\mathrm{VI})$.

\section{Discussion}

Although, liver is an organ of vital significance due to its crucial role in maintaining the biological equilibrium of vertebrates but the drug metabolizing enzymes are also present at other sites. However, diverse types of hepatic dysfunctions and varied sites of action of different drugs may result in increased drug action and reduced drug elimination. In such cases, the extrahepatic organs and tissues supplement the metabolism of toxic chemical insults using xenobiotic metabolizing enzymes to a specific extent. ${ }^{3}$ The activities of the drug metabolizing enzymes representing major classes of enzymatic machinery (oxidation, reduction, hydrolysis and conjugation) are known to be present in the subcellular fractions of human renal cortex, lung, gastric mucosa, colonic mucosa, spleen and prostate to certain degrees. ${ }^{45}$ The first pass

Table 4. Modulation of DMBA induced impairment of antioxidant enzymes by betulinic acid among different treatment groups of female Sprague Dawley rats.

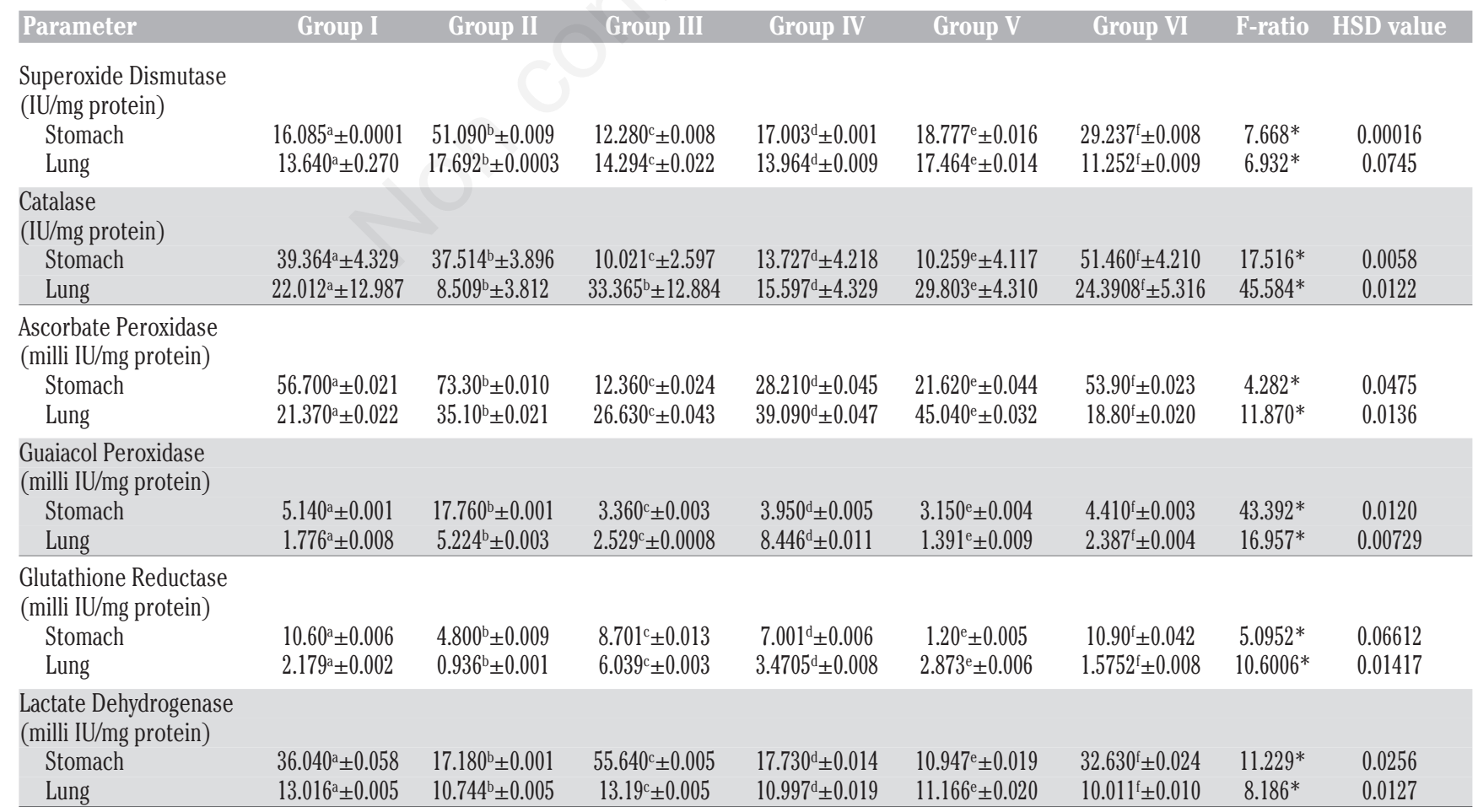

*Represents significance at $\mathrm{P} \leq 0.05$. Superscripts a-f represents comparison of group I, II, III, IV, V and VI means using HSD value. 
metabolism in gastrointestinal tract (GIT) may also establish the equilibrium between bioactivation/deactivation for orally ingested xenobiotics. ${ }^{46}$ Both rodent and human GIT contain enzymes capable of metabolizing a broad range of xenobiotics. ${ }^{47}$ The presence of food in the rat stomach influences the bioavailabilty and pharmacokinetics of these chemicals. ${ }^{48}$ The interaction of pesticides with P-glycoproteins was reported to be upregulated in rat stomach, jejunum and liver. ${ }^{49}$ In another report, presence of benzo(a)pyrene hydroxylase in GIT, lungs and skin suggests that these tissues act as portals of entry and site of metabolism in the body and metabolize the noxious agents. ${ }^{50}$

In the present study, a polycyclic aromatic hydrocarbon (DMBA) was chosen for its ability to imbalance the different biochemical parameters with the consideration that this compound is readily metabolized into reactive carcinogens to form DNA adduct. ${ }^{51}$ Figure 1 shows the possible fate of DMBA after administration into the body. Betulinic acid has received a lot of attention because of its enthusiastic biochemical modulatory influences both in in vitro and in vivo system. The current study employed the use of female Sprague Dawley rats as a number of studies in literature reveals that a high incidence of spontaneous tumors $(57 \%)$ occur in normal female rats extended over their entire adult life. The male rats of same strain were found to be less susceptible to tumor formation than females. ${ }^{52,53}$ The protocol was followed for 7 weeks and was terminated at the end $14^{\text {th }}$ week in order

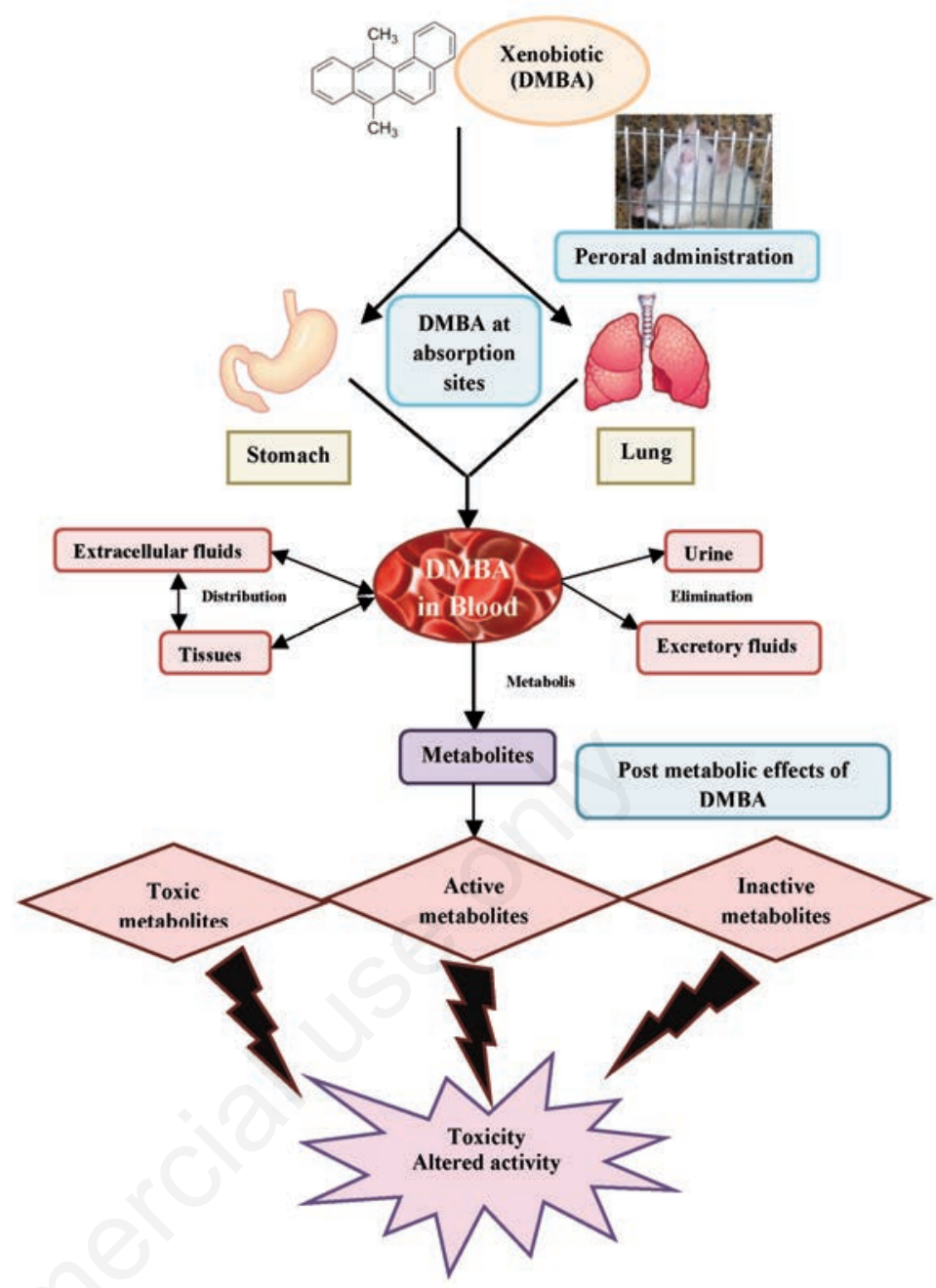

Figure 1. Schematic representation of possible fate of DMBA after administration into the body.

Table 5. Modulation of DMBA induced impairment of oxidative stress parameters by betulinic acid among different treatment groups of female Sprague Dawley rats.

\begin{tabular}{|c|c|c|c|c|c|c|c|c|}
\hline Parameter & Group I & Group II & Group III & Group IV & Group V & Group VI & F-ratio & HSD value \\
\hline \multicolumn{9}{|c|}{$\begin{array}{l}\text { Lipid Peroxidation (TBARS) } \\
\text { ( } \mu \text { moles MDA equivalent/g } \\
\text { of tissue) }\end{array}$} \\
\hline Stomach & $117.913^{\mathrm{a}} \pm 0.003$ & $119.632^{\mathrm{b}} \pm 0.002$ & $139.983^{c} \pm 0.006$ & $65.728^{\mathrm{d}} \pm 0.009$ & $110.762^{\mathrm{e}} \pm 0.008$ & $121.213^{\mathrm{f}} \pm 0.01$ & $20.021^{*}$ & 0.0384 \\
\hline Lung & $19.594^{\mathrm{a}} \pm 0.001$ & $44.483^{b} \pm 0.017$ & $29.564^{\mathrm{c}} \pm 0.007$ & $42.971^{\mathrm{d}} \pm 0.003$ & $15.675^{\mathrm{e}} \pm 0.006$ & $43.315^{\mathrm{f}} \pm 0.004$ & $3.113^{*}$ & 0.0503 \\
\hline \multicolumn{9}{|c|}{$\begin{array}{l}\text { Lipid Hydroperoxides } \\
\text { (mM } \mathrm{H}_{2} \mathrm{O}_{2} \text { equivalents/g } \\
\text { of tissue) }\end{array}$} \\
\hline Stomach & $1.582 \pm 0.004$ & $0.730 \pm 0.01$ & $4.077 \pm 0.012$ & $1.345 \pm 0.013$ & $1.906 \pm 0.017$ & $2.190 \pm 0.009$ & 0.1445 & - \\
\hline Lung & $2.522^{\mathrm{a}} \pm 0.006$ & $0.983^{b} \pm 0.004$ & $2.924^{c} \pm 0.006$ & $1.367^{\mathrm{d}} \pm 0.008$ & $1.767^{\mathrm{e}} \pm 0.002$ & $1.401^{\mathrm{d}} \pm 0.021$ & $8.017^{*}$ & 0.0558 \\
\hline \multicolumn{9}{|c|}{$\begin{array}{l}\text { Reduced Glutathione } \\
\text { ( } \mu \mathrm{M} \text { of SH content/g of tissue) }\end{array}$} \\
\hline Stomach & $764.130^{\mathrm{a}} \pm 0.001$ & $523.460^{\mathrm{b}} \pm 0.002$ & $1895.310^{c} \pm 0.010$ & $1744.88 \mathrm{~d} \pm 0.003$ & $625.750^{\mathrm{e}} \pm 0.001$ & $1143.20^{\mathrm{f}} \pm 0.002$ & $4.659^{*}$ & 0.0216 \\
\hline Lung & $1186.610 \pm 0.008$ & $983.770 \pm 0.002$ & $2216.02 \pm 0.008$ & $2190.0 \pm 0.002$ & $1222.110 \pm 0.002$ & $1566.930 \pm 0.003$ & 0.6193 & - \\
\hline \multicolumn{9}{|c|}{$\begin{array}{l}\text { Protein Content } \\
\text { (mg/g of tissue) }\end{array}$} \\
\hline Stomach & $40.140^{\mathrm{a}} \pm 0.043$ & $17.540^{\mathrm{b}} \pm 0.02$ & $67.180^{c} \pm 0.02$ & $39.420^{\mathrm{d}} \pm 0.007$ & $135.020^{\mathrm{e}} \pm 0.033$ & $27.340^{\mathrm{f}} \pm 0.006$ & $71.401^{*}$ & 0.1194 \\
\hline Lung & $63.916 \mathrm{a} \pm 0.005$ & $57.233^{\mathrm{b}} \pm 0.004$ & $30.166^{c} \pm 0.011$ & $54.816^{\mathrm{d}} \pm 0.002$ & $41.033^{\mathrm{e}} \pm 0.001$ & $61.233^{\mathrm{f}} \pm 0.031$ & $20.114^{*}$ & 0.0832 \\
\hline
\end{tabular}

*Represents significance at $\mathrm{P} \leq 0.05$. Superscripts a-f represents comparison of group I, II, III, IV, V and VI means using HSD value. 
to develop the toxic effects of DMBA on the extrahepatic organs and to observe the impact of betulinic acid on DMBA evoked damage.

The level of lipid peroxides (LPO) is the diagnostic index for evaluating the extent of membrane damage as it causes polymerization, cross-linking and/or fragmentation of the membrane components leading to altered membrane permeability and destructing cellular constituents like lipids, proteins and nucleic acids. ${ }^{54} \mathrm{Na}^{+} / \mathrm{K}^{+}$ATPase, a membrane-bound enzyme, is essential to maintain the $\mathrm{Na}^{+}$and $\mathrm{K}^{+}$gradients between the cells and their environment. ${ }^{55} \mathrm{Ca}^{2+}$-ATPase is of primary importance in control of hydration, volume, nutrient uptake, contractility and excitability of muscles. ${ }^{56,57} \mathrm{Mg}^{2+}$-ATPase regulates the rate of protein synthesis and cell growth. ${ }^{58}$ In the present investigation, administration of DMBA increased the activities of physiologically important membrane bound ATPases namely, $\mathrm{Na}^{+} / \mathrm{K}^{+}$-ATPase, $\mathrm{Ca}^{2+}$ ATPase and $\mathrm{Mg}^{2+}$-ATPase. Disturbances in the ionic equilibrium of ATPases might be due to the failure of optimal interaction with the membrane components, as an outcome of increased LPO. Co-treatment of betulinic acid caused the modification in the altered membrane fluidity and thereby improved the cell membrane integrity as a result of enhancement of GSH and protection against LPO provided by the treatment.

The disposition of DMBA and thereby defense against oxidative injury occurs in the presence of several detoxification enzymes. One of the important pathways is GSH conjugation catalyzed by GST that is concerned with the elimination of the proximate and ultimate carcinogens through formation of more water-soluble and non-electrophilic detoxification products. ${ }^{59}$ DTdiaphorase acts as a chemical detoxifier, superoxide scavenger and maintains endogenous antioxidant vitamins. ${ }^{60}$ Elevated expressions of GST and DTdiaphorase cited in several previous reports are well in line with our findings. ${ }^{61,62}$ This might be due to the reason that PAHs activate transcription of GST and DTdiaphorase by binding to the xenobiotic response element present in the promoter region of genes. ${ }^{63}$

The antioxidant enzyme activity varies from tissue to tissue and also depends on the continuance and rigor of the toxin. SOD and CAT acts as mutually supportive antioxidants and provide protective defence against reactive oxygen species (ROS). The enhancement of the various antioxidant enzymes viz., SOD, CAT, APOX and GPOX indicates the presence of more oxygen free radicals in the system. This increase might be due to the activation of genes that code for antioxidant enzymes by oxidants. ${ }^{64}$ The reduction in the enzyme status of almost all the antioxidant related enzymes by betulinic acid supplementation in comparison to DMBA recipient rats explains its significance in eliminating free radical-mediated consequences that may affect the normal functioning of cells. GR catalyzes the reduction of glutathione disulfide by NADPH. ${ }^{65}$ The diminution in the GR activity in DMBA administered rats might be ascribable to the decline in the production and availability of reduced glutathione to overcome $\mathrm{H}_{2} \mathrm{O}_{2}$ as GR is responsible for regeneration of GSH. On the contrary, the expression of GR was increased on treatment with betulinic acid suggesting GSH-dependent detoxification of free radicals as GSH is one of the guarding factors against oxidative stress. LDH, a cytoplasmic marker enzyme catalyses the readily reversible reaction involving oxidation of lactate to pyruvate and serves as a biochemical indicator of organ dysfunction, differentiates normal tissues from their damaged counterparts and spot various stages of tissue development. ${ }^{66,67}$ In the present investigation, damage to stomach and lung tissues by DMBA is reflected by a substantial decrease in the activity of LDH showing suppressed lactate metabolism. Furthermore, LDH is believed to vary according to the metabolic necessity of each tissue and alteration in LDH levels have been observed during development under changing biological conditions and in response to pathological processes. ${ }^{68}$

Oxidative damage is an indicator of the diseases caused by disruption in tissue functions. The process of lipid peroxidation is under the control of efficient endogenous cellular defense systems that ensures optimum metabolic functions. In this study, an increase in lipid peroxidation was observed in DMBA group of both extrahepatic organs due to the production of excessive, toxic and diffusible ROS during the metabolism of DMBA indicating the damage to cell membranes and cellular dysfunction. Treatment with betulinic acid reduced the level of MDA, which could be associated with its protective role as a free radical scavenger. GSH, a co-factor for several detoxifying enzymes has a putative role in regulation of cell proliferation, reduction of peroxides and maintenance of protein thiols in the reduced state. The present investigation showed a declined level of reduced glutathione in DMBA administered rats. The reduction in GSH content is associated with disproportionate synthesis of ROS coupled with the lessened activity of gluco-6-phosphate dehydrogenase, a GSH-synthesizing enzyme. ${ }^{69,70} \mathrm{Co}$-administration of betulinic acid credited its biological significance by

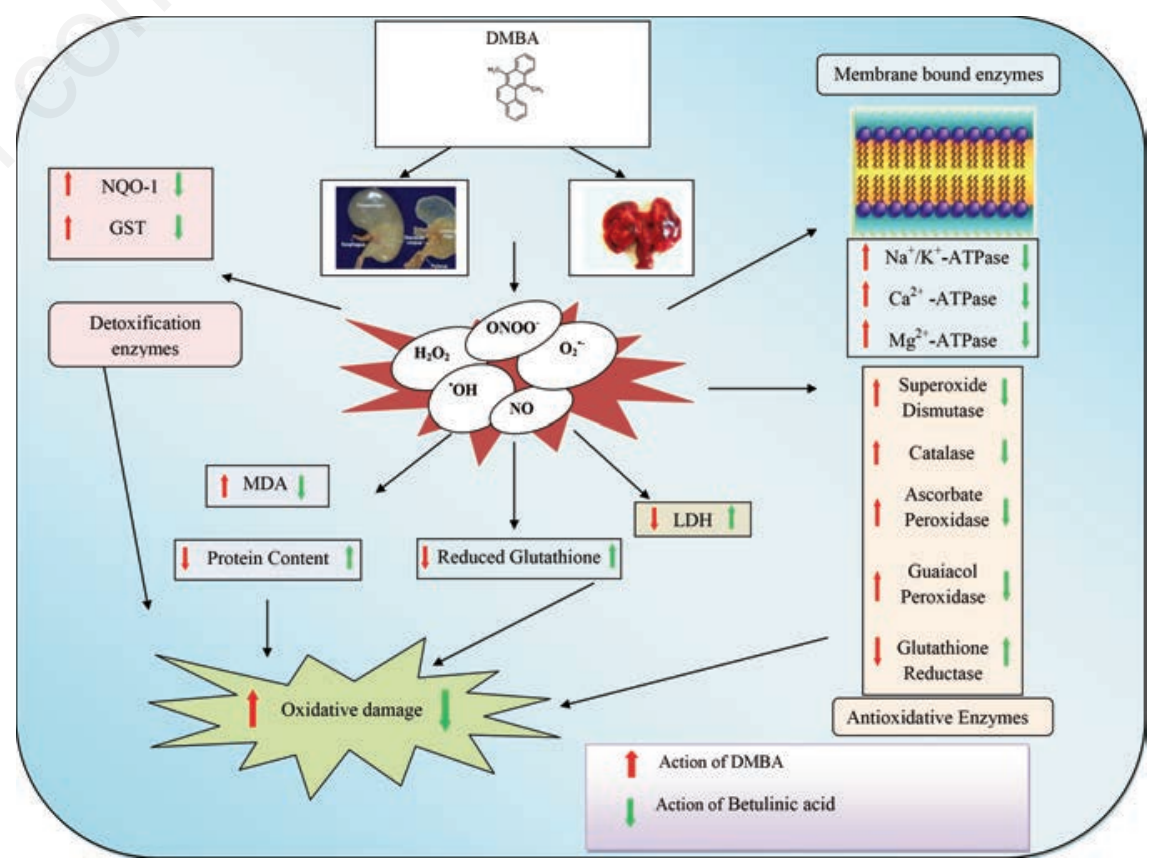

Figure 2. Overall schematic representation of Betulinic acid mediated modulation of DMBA evoked extrahepatic oxidative injury. 
elevating the level of GSH and thus, protecting cellular proteins against oxidative stress.

Variations in the protein content among different groups is related to the oxidative stress that cause DNA, protein and lipid damage leading to changes in chromosome instability, genetic mutations or modulations in cell growth. ${ }^{71}$

\section{Conclusions}

In nutshell, we conclude that the normal cellular protective response is altered by tissue damage caused by a xenobiotic. This damage depends on the bioavailability of xenobiotic, its metabolism and various other factors. The damaging effect of DMBA is realized through the formation of free radicals or ROS, activation of membrane lipid peroxidation, their release in circulation, disturbances in energy homoeostasis, altered enzymatic machinery and thus, failure of adaptive potential of body to conditions of increased oxidative stress. Betulinic acid controlled the formation and release of free radical cascades thereby reducing toxic side-effects in animals (Figure 2).

\section{Research highlights}

- Extrahepatic organs cope up with scores of xenobiotics by acting as first line detoxification defense.

- Betulinic acid neutralizes the oxidant radicals evoked by such xenobiotics (DMBA) in extrahepatic sites maintaining electrophysiological energetic and cellular homeostasis.

- Thus, betulinic acid offers protection against tissue damage induced by DMBA.

\section{References}

1. Caldwell J, Gardner I, Swale N. An introduction to drug disposition: the basic principles of absorption, distribution, metabolism and excretion. Toxicol Pathol 1995;23:102-14.

2. Robin, Arora S, Vig AP. Inhibition of DNA oxidative damage and antimutagenic activity by dichloromethane extract of Brassica rapa var. rapa L. seeds. Ind Crops Prod 2015;74:585-91.

3. Kyegombe D. Clinical and pharmacological significance of extrahepatic drug metabolism in man. Bahrain Med Bull 1990;12:29-32.

4. Sampson HA. Food hypersensitivity: manifestations, digestions and natural history. Food Tech 1992;41-144.

5. Kashaw V, Nema AK, Agarwal A. Hepatoprotective prospective of herbal drugs and their vesicular carriers - a review. Int $\mathrm{J}$ Pharma Bio Sci 2011;2:360-74.

6. Smyth HDC, Hickey AJ. Controlled pulmonary drug delivery, Advances in delivery science and technology. New York: Springer-Verlag; 2011.

7. Aoki M, Okudaira K, Haga M, Nishigaki R, Hayashi M. Contribution of rat pulmonary metabolism to the elimination of lidocaine, midazolam and nifedipine. Drug Metab Dispos 2011;38:1183-8.

8. Yost GS. Sites of metabolism: lung. In: Woolf TF, ed. Handbook of drug metabolism. New York: Marcel Dekker Inc; 1999. pp 263-78.

9. Perreault S, Dumont L, Villiere V, Ong H, Adam A, du Souich P. Hepatic and extrahepatic metabolism of salbutamol in anesthetized rabbits. Drug Metab Dispos 1993;21: 485-91.

10. National Institute of Health. Division of occupational health and safety. 7,12Dimethylbenz[a]anthracene safety datasheet; 1993.

11. Grant R. Cancer induction in the glandular stomach of rats at sites of implanted 7,12-Dimethylbenz[a]anthracene. J Natl Cancer Inst 1966;37:353-64.

12. Wattenberg LW. Inhibition of carcinogenic effects of polycyclic hydrocarbons by benzyl isothiocyanate and related compounds. J Natl Cancer Inst 1977;58:395-8.

13. Maltoni C, Prodi G. Effect of 9,10dimethyl-1,2-benzanthracene injected intraperitoneally into the rat. Tumori 1959;45:71-85.

14. Dipple A, Bigger CA. Mechanism of action of food-associated polycyclic aromatic hydrocarbon carcinogens. Mutat Res 1991;259:263-6.

15. Recio MC, Giner RM, Manez S, Gueho J, Julien HR, Hostettmann K, Rios JL. Investigations on the steroidal antiinflammatory activity of triterpenoids from Diospyros leucomelas. Planta Med 1995;61:9-12.

16. Martelanc M, Vovk I, Simonovska B. Determination of three major triterpenoids in epicuticular wax of cabbage (Brassica oleracea L.) by high-performance liquid chromatography with UV and mass spectrometric detection. J Chromatogra A 2007; 1164:145-52.

17. Kumar D, Mallick S, Vedasiromoni JR, Pal BC. Anti-leukemic activity of Dillenia indica L. fruit extract and quantification of $3 \beta$, hydroxy-lup- 20(29)-en-28-oic acid by HPLC. Phytomedicine 2010;17:431-5.

18. Mukherjee PK, Saha K, Das J, Pal M, Saha BP. Studies on the anti-inflammatory activity of rhizomes of Nelumbo nucifera. Planta Med 1997;63:367-9.

19. Clercq DE. Antiviral therapy for human immunodeficiency virus infections. Clin Microbiol Rev 1995;8:200-39.

20. Fulda S. 3ß, hydroxy-lup-20(29)-en-28oic acid: a natural product with anticancer activity. Mol Nutr Food Res 1995;53:140-6.

21. Pisha E, Chai H, Lee IS, Chagwedera TE, Farnsworth NR, Cordell G, et al. Discovery of 3 $\beta$, hydroxy-lup-20(29)en-28-oic acid as a selective inhibitor of human melanoma that functions by induction of apoptosis. Nat Med 1995;1:1046-51.

22. Hashimoto F, Kashiwada Y, Cosentino LM, Chen $\mathrm{CH}$, Garrett PE, Lee KH. Anti-AIDS agents-XXVII. Synthesis and anti-HIV activity of $3 \beta$, hydroxylup-20(29)-en-28-oic acid and dihyro3 $\beta$, hydroxy-lup-20(29)-en-28oic acid derivatives. Bioorg Med Chem 1997;5:2133-43.

23. Kessler JH, Mullauer FB, de Roo GM, Medema JP. Broad in vitro efficacy of plant-derived $3 \beta$, hydroxy-lup-20(29)en-28-oic acid against cell lines derived from the most prevalent human cancer types. Cancer Lett 2007;251:132-45.

24. Fulda S, Debatin KM. $3 \beta$, hydroxy-lup20(29)-en-28-oic acid induces apoptosis through a direct effect on mitochondria in neuroectodermal tumors. Med Pediatr Oncol 2000;35:616-8.

25. Syrovets T, Buchele B, Gedig E, Slupsky JR, Simmet T. Acetylboswellic acids are novel catalytic inhibitors of human topoisomerases I and II alpha. Mol Pharmacol 2000;58:71-81.

26. Kaur R, Arora S. Interactions of $3 \beta$, hydroxy-lup-20(29)-en-28-oic acid with xenobiotic metabolizing and antioxidative enzymes in 7,12Dimethylbenz(a)anthracene-treated Sprague Dawley female rats. Free Radic Biol Med 2013;65:131-42.

27. Wijnhoven SWP, Kool HJM, Mullenders LHF, Slater R, Zeeland AA, Vrieling H. 7,12-Dimethylbenz(a) anthracene-induced toxic and mutagenic responses vary dramatically between NER deficient Xpa, Xpc and Csb mice. Carcinogenesis 2001;22:1099-106.

28. Bonting SL. Sodium-potassium activated adenosine triphosphatase and cation transport. In: Bitter EE, ed. Membrane ion transport. Chichester: Inter Science; 
1970. pp 257-63.

29. Hjerten S, Pan H. Purification and characterization of two forms of a low affinity $\mathrm{Ca} 2+-\mathrm{ATPase}$ from erythrocyte membranes. Biochim Biophys Acta 1983;728:281-8.

30. Ohnishi T, Suzuki T, Suzuki Y, Ozawa KA. A comparative study of plasma membrane $\mathrm{Mg} 2+-$ ATPase activities in normal, regenerating and malignant cells. Biochim Biophys Acta 1982;684:67-74.

31. Fiske $\mathrm{CH}$, Subbarow Y. Calorimetric determination of phosphorous. J Biol Chem 1925;66:375-400.

32. Habig WH, Pabst MJ, Jakoby WB. Glutathione-S-transferases. The first enzymatic step in mercapturic acid formation. J Biol Chem 1974;249:7130-9.

33. Ernster L. DT-diaphorase. In: Estabrook RW, Pullman ME, eds. Methods in enzymology. New York: Academic Press; 1967. pp 309-17.

34. Kono Y. Generation of superoxide radical during autoxidation of hydroxylamine and an assay for superoxide dismutase. Arch Biochem Biophys 1978;186:189-95.

35. Aebi H. Catalase in vitro. In: Colowick SP, Kaplan NO, eds. Methods in enzymology. New York, Academic Press; 1984. pp 121-6.

36. Asada K. Ascorbate peroxidase - a hydrogen peroxide-scavenging enzyme in plants. Physiol Plant 1992;85:23541.

37. Putter J. Peroxidase. In: Bergmeyer HU, ed. Methods of enzymatic analysis. Weinhan, Verlag Chemie; 1974. pp 685 90.

38. Carlberg I, Mannervik B. Glutathione reductase. In: Meister A, ed. Methods in enzymology. New York: Academic Press; 1975. pp 484-90.

39. Kuznetsov AV, Gnaiger E. Laboratory protocol: Lactate dehydrogenase. Cytosolic marker enzyme. Mitochondr Physiol Network 2010;18:1-8.

40. Devasagayam TP, Boloor KK, Ramasarma T. Methods for estimating lipid peroxidation: an analysis of merits and demerits. Indian $\mathrm{J}$ Biochem Biophys 2003;40:300-8.

41. Jiang ZY, Hunt JV, Wolff SP. Ferrous ion oxidation in the presence of xylenol orange for detection of lipid hydroperoxides in low density lipoprotein. Anal Biochem 1992;202:384-9.

42. Anderson ME. Determination of glutathione and glutathione disulfide in biological samples. In: Meister A, ed. Methods in enzymology. New York: Academic Press; 1985. pp 548-51.

43. Smith PK, Krohn RI, Hermanson GT,
Mallia AK, Gartner FH, Provenzano $\mathrm{MD}$, et al. Measurement of protein using bicinchoninic acid. Anal Biochem 1985;150:76-85.

44. Rauchova H, Ledvinkova J, Kalous M, Drahota Z. The effect of lipid peroxidation on the activity of various membrane-bound ATPases in rat kidney. Int J Biochem Cell Biol 1995;27:251-5.

45. Franklin CS, Kyegombe DB. The distribution and induction of some drugmetabolising enzymes in man. $\mathrm{Br} \mathrm{J}$ Pharmacol 1973;47:616.

46. Wacher VJ, Salphati L, Benet LZ. Active secretion and enterocytic drug metabolism barriers to drug absorption. Adv Drug Deliv Rev 2001;46:89-102.

47. Obach RS, Zhang QY, Dunbar D, Kaminsky LS. Metabolic characterization of the major human small intestinal cytochrome p450s. Drug Metab Dispos 2001;29:347-52.

48. Melander A. Influence of food on the bioavailability of drugs. Clinical Pharmacokinet 1978;3:337-51.

49. Lanning CL, Fine RL, Sachs CW, Rao US, Corcoran JJ, Abou-Donia MB. Chlorpyrifos oxon interacts with the mammalian multidrug resistance protein, P-glycoprotein. J Toxicol Environ Health 1996;47:395-407.

50. Rahimtula AD, Zachariah PK, Obrien PJ. Differential effects of antioxidants, steroids and other compounds on benzo(a)pyrene 3-hydroxylase activity in various tissues of rat. $\mathrm{Br} \mathrm{J}$ Cancer 1979;40:105-12.

51. Wibowo AE, Sriningsih PE, Wuyung Ranasasmita R. The influence of 7,12Dimethylbenz(a)anthracene $\quad(7,12-$ dimethylbenz-[a]anthracene) regimen in the development of mammae carcinogenesis on Sprague Dawley female rat. Int J Canc Chemoprev 2010;1:60-6.

52. Davis RK, Stevenson GT, Busch KA. Tumor incidence in normal spraguedawley female rats. Cancer Res 1956;16:194-7.

53. Prejean JD, Peckham JC, Casey AE, Griswold DP, Weisburger EK, Weisburger JH. Spontaneous tumors in sprague-dawley rats and swiss mice. Cancer Res 1973;33:2768-73.

54. Glitsch HG. Electrophysiology of the sodium-potassium-ATPase in cardiac cells. Physiol Rev 2001;81:1791-826.

55. Park JS, Chyun JH, Kim YK, Line LL, Chew BP. Astaxanthin decreased oxidative stress and inflammation and enhanced immune response in humans. Nutr Metab 2010;5:7-18.

56. Levy J, Gavin JR, Sowers JR. Diabetes mellitus: a disease of abnormal cellular calcium metabolism? Am J Med
1994;96:260-73.

57. Golfman LS, Takeda N, Dhalla NS. Cardiac membrane $\mathrm{Ca} 2+$-transport in alloxan induced diabetes in rats. Diabetes Res Clin Pract 1996;31:S73-7.

58. Tsakiris S, Marinou K, Schulpis KH. The in vitro effects of galactose and its derivatives on rat brain $\mathrm{Mg} 2+-\mathrm{ATPase}$ activity. Pharmacol Toxicol 2002;91:254-7.

59. Kabler SL, Seidel A, Jacob J, Doehmer J, Morrow CS, Townsend AJ. Differential protection by human glutathione S-transferase P1 against cytotoxicity of benzo[a]pyrene, dibenzo[a,l]pyrene, or their dihydrodiol metabolites, in bi-transgenic cell lines that co-express rat versus human cytochrome P4501A1. Chem Biol Interact 2009;179:240-6.

60. Dinkova-Kostova AT, Talalay P. $\mathrm{NAD}(\mathrm{P}) \mathrm{H}$ :quinone acceptor oxidoreductase 1 (NQO1), a multifunctional antioxidant enzyme and exceptionally versatile cytoprotector. Arch Biochem Biophys 2010;501:116-23.

61. Balasenthil S, Saroja M, Ramachandran $\mathrm{CR}$, Nagini S. Of humans and hamsters: comparative analysis of lipid peroxidation, glutathione and glutathione-dependent enzymes during oral carcinogenesis. $\mathrm{Br} \mathrm{J}$ Oral Maxillofac Surg 2000;38:267-70

62. Mikami K, Naito M, Ishiguro T, Yano $\mathrm{H}$, Tomida A, Yamada $\mathrm{T}$, et al. Immunological quantitation of DTdiaphorase in carcinoma cell lines and clinical colon cancers: advanced tumors express greater levels of DT-diaphorase. Jpn J Cancer Res 1998;89:910-5.

63. Flora SD, Ramel C. Mechanisms of inhibitors of mutagenesis and carcinogenesis. Classification and overview. Mutat Res 1988;202:285-306.

64. Zhou Y, Hileman EO, Plunkett W, Keating MJ, Huang P. Free radical stress in chronic lymphocytic leukemia cells and its role in cellular sensitivity to ROS-generating anticancer agents. Blood 2003;101:4098-104.

65. Mannervik B. Measurement of glutathione reductase activity. Curr Protoc Toxicol 2001; doi: 10.1002/0471140856.tx0702s00.

66. Kaplan NO. Effect of hormones and environmental factors on lactic dehydrogenases. J Cell Physiol 1965;66:110.

67. Cassidy WM, Reynolds TB. Serum lactic dehydrogenase in the differential diagnosis of acute hepatocellular injury. J Clin Gasteroenterol 1994;19:118-21.

68. Joshi PS, Chougule M, Dudanakar M, Golgire S. Comparison between sali- 
vary and serum lactate dehydrogenase levels in patients with oral leukoplakia and oral squamous cell carcinoma- a pilot study. Int J Oral Maxillofac Pathol 2012;3:7-12.

69. Goyal PK, Verma P, Sharma P, Parmar J, Agarwal A. Evaluation of anti-cancer and anti-oxidative potential of
Syzygium cumini against benzo(a)pyrene $(\mathrm{BaP})$ induced gastric carcinogenesis in mice. Asian Pac J Cancer Prev 2010;11:753-8.

70. Purushothaman A, Nandhakumar E, Sachdanandam P. Modulation of lipid peroxidation and antioxidant status upon administration of 'Shemamruthaa' in 7,12-dimethylbenz[a]anthracene induced mammary carcinoma bearing rats. Asian Pac J Trop Biomed 2012;2:S765-71.

71. Klaunig JE, Kamendulis LM, Hocevar BA. Oxidative stress and oxidative damage. Toxicol Pathol 2014;38:96109. 